\title{
Cowries graze verongid sponges on Caribbean reefs
}
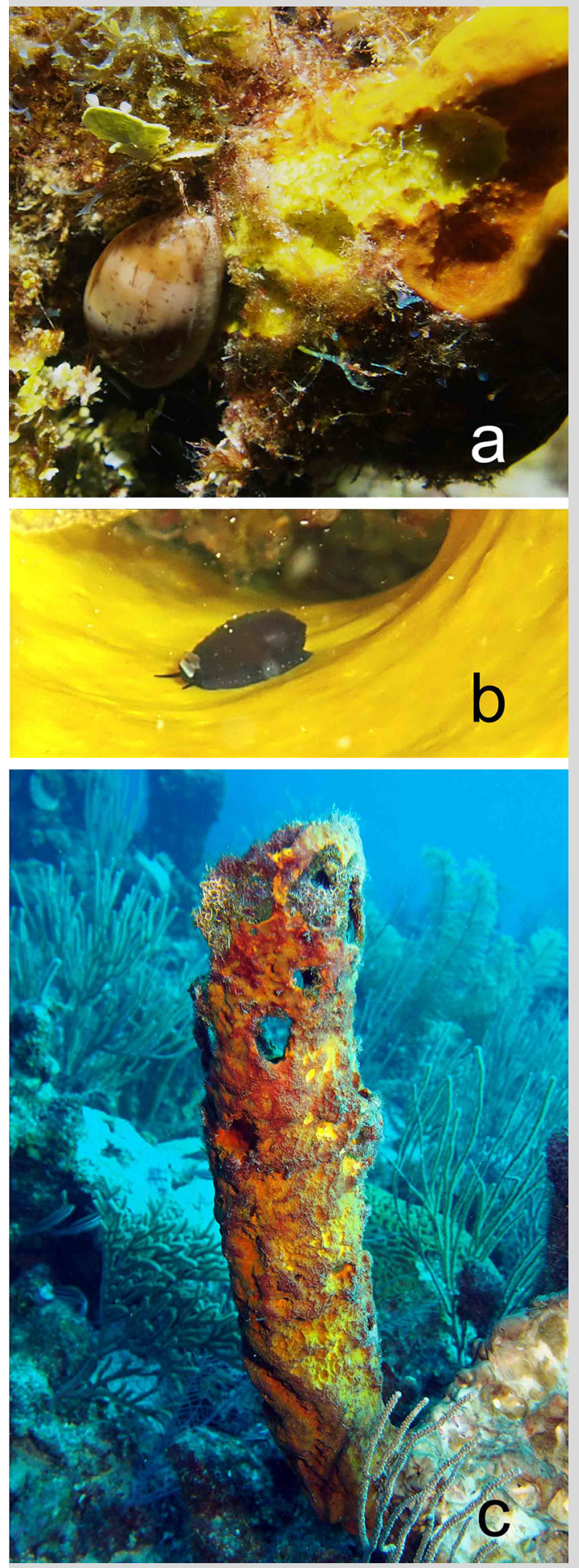

Cowries are prominently featured in shell collections worldwide, but their ecology is little known because these snails are mostly nocturnal and cryptic (Hayes 1983). While documenting fish predation on sponges around the Caribbean (Loh and Pawlik 2014), we observed grazing scars on chemically defended verongid sponges (Aplysina, Ailochroia, and Verongula spp.). Here, we report that these scars may be caused by nocturnally active cowries. Other mollusks, particularly shell-less dorid nudibranchs, are well known to feed on sponges. During night dives on reefs off Carrie Bow Cay, Belize, small cowries (Luria cinerea) were observed on or adjacent to shallow-linear and deep-hemispherical scars on verongiid sponges, particularly Aplysina fistularis. In one case, a cowrie was photographed just after actively feeding on A. fistularis (Fig. 1a). While most of the scars on sponges were associated with cowries that had emerged from reef crevices (Fig. 1a), several sponge tubes were found to contain 2-3 adult cowries living in the inside bottom of the tube along with egg cases and several small juveniles (Fig. 1b). These sponge tubes appeared diseased (Fig. 1c), consistent with the effects of sustained grazing on their inner and outer surfaces. Because chemically defended sponge species heal wounds very slowly (Walters and Pawlik 2005), cowrie grazing scars may persist for months or years.

Acknowledgments Funded by NSF (OCE 1029515). Thanks to N. Patin and P. Jensen for field assistance and to G. Rouse for molecular sequencing of tissue from adult and juvenile cowrie specimens to confirm species identity.

\section{References}

Hayes T (1983) The influence of diet on the local distribution of Cypraea. Pac Sci 37:27-36

Loh T-L, Pawlik JR (2014) Chemical defenses and resource trade-offs structure sponge communities on Caribbean coral reefs. Proc Natl Acad Sci USA 111:4151-4156 Walters KD, Pawlik JR (2005) Is there a trade-off between wound-healing and chemical defenses among Caribbean reef sponges? Integr Comp Biol 45:352-358

4 Fig. 1 Cowrie Luria cinerea and prey sponge Aplysina fistularis. a Cowrie retracting into its shel after leaving feeding scars along the base of the sponge (shell length $\sim 2.0 \mathrm{~cm}$ ), b juvenile cowrie crawling inside the sponge tube (length $\sim 5.0 \mathrm{~mm}$ ), and $\mathbf{c}$ sponge that contained several adult and juvenile cowries inside the base of the tube (height $\sim 40.0 \mathrm{~cm}$ )

J. R. Pawlik $(\bowtie)$ - L. K. Deignan

Center for Marine Science, University of North Carolina Wilmington, 5600

Marvin K. Moss Lane, Wilmington, NC 28409, USA

e-mail: pawlikj@uncw.edu
Received: 17 December 2014/ Accepted: 20 February 2015/Published online: 27 February 2015

(C) Springer-Verlag Berlin Heidelberg 2015
Coral Reefs (2015) 34:663 DOI $10.1007 / \mathrm{s} 00338-015-1279-\mathrm{x}$ 